\title{
RABA NEDOLOČNIH KOLIČINSKIH ZAIMKOV V DVEH FRANCOSKO-SLOVENSKIH KORPUSIH: V SPOOKU IN V EVROKORPUSU
}

Pričujoči članek predstavlja analizo francoskih in slovenskih nedoločnih kvantifikatorjev: delnih (plusieurs/več, quelques/nekaj, quelques-uns/nekateri, certains/nekateri) in celostnih (tout/vsak, tous/vsi, chaque/vsak, chacun/vsakdo). Že na začetku smo obravnavane besede združili pod nadpomenko kvantifikatorji. Zaimkovne izraze količine smo splošno poimenovali nedoločni kvantifikatorji. S to terminološko rešitvijo smo poleg zaimkov vključili tudi pridevnike z istimi oblikami. Funkcija nedoločnih kvantifikatorjev je določanje referentov iz jezikovnega okolja in njihova vpeljava v kontekst. Ko se premaknemo na področje izražanja količine, je njihova nedoločnost večja. Toda nedoločnost se tu nanaša le na določevanje količine. Ekstenziteta količine, ki jo zaznamujejo, je odvisna od številnih dejavnikov: semantičnih, kognitivnih in zunajjezikovnih.

$\mathrm{Z}$ raziskavo smo analizirali primerjavo izbranih nedoločnih kvantifikatorjev vzporednega francosko-slovenskega korpusa Spook in francosko-slovenskega dela Evrokorpu$s a$. Izvedli smo kvantitativno in kvalitativno kontrastivno primerjavo pojavljanja izbranih nedoločnih kvantifikatorjev. Iz vzporednih besedil smo želeli dobiti vpogled v dejanske prevodne rešitve. $Z$ izbiro teh dveh korpusov smo posegli na literarno, publicistično in pravno področje. $\mathrm{V}$ analizi korpusnih rešitev smo pregledali pojavnice nedoločnih količinskih zaimkov, njihove prevodne ustreznice in izpuste.

Kontrastivno-semantična analiza ne predstavlja le zaporedja posameznih jezikovnih enot (besed), ki bi se jih dalo pretvoriti v drug jezik, temveč analizira tudi prenos pomena, ki ga vsebujejo te enote. Dvoumnosti, do katerih prihaja predvsem pri prevodnih ustreznicah posameznih besed v slovarjih, tako niso posledica strukture besedila, temveč posledica razlik v jezikovnem sistemu (Sinclair 1984). Kontrastivni pristop nam omogoča pogled na jezik, ki upošteva določena pravila, hkrati pa s semantičnimi vrednostmi posega izven teh pravil jezika kot sistema. Ker tudi semantičnih analiz in rezultatov ne moremo več prepustiti le intuiciji, moramo imeti instrumente, da jih preverimo, ponovimo in se na njih lahko zanesemo. To nam omogočajo pisni in govorni korpusi, poleg tega pa še slovarji in rojeni govorci (Weigand 1988: 27-28). 
Članek je zasnovan v iskanju natančnejšega pomena kvantifikatorjev in v iskanju morebitne meje dosega nedoločnih kvantifikatorjev $\mathrm{v}$ francoščini in slovenščini. $\mathrm{V}$ teoretičnem izhodišču temelji na Corblinovem modelu referenčnih interpretacij (1987). Njegova videnja smo dopolnili še z modelom Bosveld-de Smet (1994), Dobrovie-Sorrin in Beyssade (2004) in Wilmeta (1986). Pri analizi dosega kvantifikatorjev smo izhajali iz Wilmetovega modela, ki doseg SZ in kvantifikatorjev razdela zelo podrobno. Poleg omenjenih avtorjev smo se naslanjali tudi na številne druge avtorje; na tem mestu omenjamo le nekatere: Gondret (1976), Van de Velde (2005), Charaudeau (1992), Kleiber (2011) in Leeman (2004), za slovenščino pa zlasti Vidovič-Muha $(1979,1996,2000)$ in Toporišič $(1966,1982,1992,2004)$ idr.

V teoretičnem izhodišču smo analizirali tudi več tradicionalnih slovnic: Grammaire du français classique et moderne (Wagner in Pinchon 1969), Le Bon Usage (Grévisse 1975), Grammaire du sens et de l'expression (Charaudeau 1992), Grammaire méthodique du français (Riegel et al. 1994), Le Bon Usage (2014). Novejše slovnice in sodobnejši avtorji (Van de Velde 2005, Flaux 2008, Dobrovie-Sorin in Beyssade 2004, ...) zagovarjajo prenovljene klasifikacije. Ugotavljajo, da členi in pridevniki zasedajo enako mesto pred samostalnikom, čeprav ne sodijo vedno v isto kategorijo. Tudi po klasični slovenski klasifikaciji (Toporišič 2004) sodijo nedoločni določevalniki k pridevnikom, zaimkom in včasih tudi $\mathrm{k}$ prislovom. Na podlagi sintaktične delitve po teoriji posplošenih kvantifikatorjev (Barwise in Cooper 1981, Milsark 1974 v Corblin 1997) smo kvantifikatorje po pomenu razdelili v dva razreda. Na delne (oz. šibke') kvantifikatorje in na celostne (oz. močne ${ }^{2}$ ).

V nadaljevanju bomo predstavili prevodne ustreznice izbranih nedoločnih kvantifikatorjev v dveh slovensko-francoskih korpusih: v Spooku ${ }^{3}$ in Evrokorpusu ${ }^{4}$ (v nadaljevanju tudi EvK). Izpis ${ }^{5}$ vseh najpogosteje rabljenih prevodnih ustreznic je potrdil obstoječe slovarske prevedke. V obeh korpusih se je izkazalo, da ima vsak nedoločni kvantifikator vedno le eno močno prevladujočo slovensko ustreznico. Poleg teh prevodnih ustreznic so nas presenetile številne druge prevodne ustreznice, katerih pojavnost potrjuje nedoločnost izbranih kvantifikatorjev. Gre za besede, ki na posreden ali neposreden način izražajo količino, hkrati pa so z večjo semantično natančnostjo vpete v kontekst. Na izbor posameznih prevodnih ustreznic vplivajo le prevajalci. In za nobeno od teh rešitev ne moremo trditi, da bi bila neustrezna. Nasprotno nam pestrost prevedkov, ki se pojavlja za posamezne nedoločne kvantifikatorje, nakazuje njihov nenatančno definiran pomen. Presenetilo nas je, da smo pri analizi prevodnih ustreznic večkrat naleteli na izpust prevoda posameznega kvantifikatorja. Tega na začetku nismo predvideli. Kljub izpustu prevedka smo ugotovili, da pomen stavka ni okrnjen. Na koncu smo dobili zelo raznolike prevodne rešitve vseh obravnavanih kvantifikatorjev in s tem zabeležili številne možnosti izražanja nedoločne količine.

1 Šibki kvantifikatorji se lahko nahajajo v stavkih $\mathrm{z}$ angleško neosebno konstrukcijo »there is ..." .

2 Močni kvantifikatorji ne morejo nastopati v stavkih $\mathrm{z}$ angleško neosebno konstrukcijo »there is ... « .

3 http://nl.ijs.si/spook/konkor/ (dostop dec. 2012 - 2016)

4 http://evrokorpus.gov.si/ (dostop dec. 2012 - 2016)

5 Podatki so bili zbrani v letih 2012 - 2016. Oba korpusa sta bila prosto dostopna. 
Izbrali smo (trenutno edina) dva slovensko-francoska pisna korpusa, ki vsebujeta različna besedila. Spook je večjezični prevodoslovni vzporedno-primerljivi korpus. V njem so združeni izvirni romani v angleškem, francoskem, italijanskem, nemškem in slovenskem jeziku. Francosko-slovenski del korpusa Spook je sestavljen iz podkorpusa literarnih in podkorpusa publicističnih besedil. V literarnem delu je 12 francoskih romanov in njihovih slovenskih prevodov, v publicističnem pa so zbrani članki iz časopisa $L e$ monde diplomatique in njihovi slovenski prevodi iz slovenske izdaje (Mezeg 2011).

Evrokorpus je zbirka vzporednih dvojezičnih korpusov prevodov evropskih jezikov, ki je nastala, da bi zagotovili čim bolj poenoteno rabo izrazov pri pripravi slovenske različice pravnih aktov EU. Pomanjkljivost Evrokorpusa je, da v njem ne moremo ugotoviti izhodiščnega jezika prevoda in zato ne moremo natančno ugotoviti morebitnih vplivov ali posledic prevajanja prevodne jezikovne verige.

$\mathrm{V}$ omenjenih dveh korpusih gre tudi za drugačno tehniko prevajanja: literarni korpus je treba prevajati »ročno« stavek za stavkom, besedila v Evrokorpusu pa so prevedena s pomočjo prevajalskih orodij. Slednja hranijo prevodne rešitve tipskih besedil, tako da v primeru, kjer je prevod že narejen, lahko prevajalec besedilo zgolj pregleda in popravi napake. Če bi moral celotno besedilo prevajati od začetka, ni nujno, da bi se odločil za enake rešitve.

Žal noben od izbranih korpusov ni referenčen, da bi predstavil celovito podobo izbranega jezika. Vzporedna korpusa predstavljata poravnavo izhodiščnega jezika s prevodom istega besedila $\mathrm{v}$ drugem jeziku. (Poravnava besedil pa omogoča tudi vpogled $\mathrm{v}$ prevajalske odločitve in strategije prevajanja.

Pri korpusni analizi ${ }^{6}$ so nas vodile hipoteze:

- da bo pri prevajanju francoskih kvantifikatorjev v slovenščino prihajalo do različnih možnih rešitev in da bo težko določiti edino ustrezno prevodno ustreznico,

- da bomo v Spooku našli večje število različnih prevodnih ustreznic (v nadaljevanju tudi: različnice) za nedoločne določevalnike in pridevnike kot v Evrokorpusu,

- $\quad$ da bodo kvantifikatorji manj izpuščani pri prevodih v Evrokorpusu, saj gre za natančen pravni jezik.

\subsection{Postopek zbiranja podatkov}

Izbrali smo korpusni pristop ${ }^{7}$ (corpus-based approach), katerega prednost je avtomatsko prepoznavanje in analiziranje vzorcev jezikovne rabe na velikih količinah avtentičnih

6 Analiza je bila narejena v sklopu doktorske disertacije $\mathrm{z}$ naslovom Zaimkovno izražanje količine $\mathrm{v}$ francoščini in slovenščini (T. Struna Berden, 2017).

7 Korpusno podprte (ang. Corpus-based) raziskave uporabljajo korpuse za preiskušanje, dokazovanje ali dopolnjevanje teorij in jezikovnih opisov, ki so nastali neodvisno od korpusnih podatkov. Pri korpusno usmerjenih (ang. Corpus-driven) raziskavah pa vsa teoretična izhodišča izhajajo iz korpusa in odsevajo jezikovno rabo, kot jo kaže korpus (Vintar in Fišer 2009: 84). 
besedil. Na podlagi izpisa konkordanc ${ }^{8}$ smo dobili osnovno sliko števila pojavnic posameznega nedoločnega določevalnika v korpusu. Ker je bilo število zadetkov visoko, a še vedno obvladljivo, smo lahko analizirali skoraj vse pojavnice. V Spooku je bilo skupaj 4.364 pojavnic, v Evrokorpusu pa 1.476. Omejiti smo se morali samo pri izpisu pojavnic kvantifikatorja tout. Pojavnice francoskih nedoločnih določevalnikov (certains, chacun(e), chaque, plusieurs, quelques, quelques-un(e)s, tou(te)s) iz obeh korpusov smo ročno pregledali in izpisali vse njihove slovenske ustreznice. Ustreznice smo na koncu statistično in semantično obdelali in prišli do rezultatov, ki jih predstavljamo v nadaljevanju.

V začetku smo vse nedoločne kvantifikatorje delili po spolu, saj smo le tako lahko dobili vse zadetke iz korpusov. Za kasnejše analize se nam delitev po spolu ni zdela pomembna, saj je spol besed $v$ francoščini in slovenščini različen in zato ne predstavlja relevantnega podatka.

Izjemo smo morali narediti pri obeh celostnih kvantifikatorjih tout(e) in tous/toutes. Razdelili smo ju po številu (ed./mn.). Njun pomen v ednini in množini se tako močno razlikuje, da ju ne moremo obravnavati skupaj. V množini izražata predvsem celost in kolektivnost, v ednini pa tudi poudarjanje in distributivno množino.

V Evrokorpusu smo naleteli na dve oviri:

- omejenost izpisa zadetkov na okoli 130 zadetkov;

- neznana jezikovna veriga prevajanja, zaradi katere ne moremo govoriti o neposrednem vplivu francoščine na slovenščino.

\subsection{Statistična analiza podatkov}

Statistične vrednosti nam dajo okvirno informacijo o pojavnicah in njihovo umestitev, vsaka nadaljnja analiza pa omogoča izbor relevantnih podatkov. Nas je zanimala raznolikost prevodov in v prevodu izpuščeni kvantifikatorji. Prevodne slovenske različnice, ki se pojavljajo v korpusih, smo zaradi lažjega branja v razpredelnico zapisovali v moški obliki ednine, v samem besedilu pa se, skladno s sobesedilno okolico, pojavljajo v ustreznem spolu, sklonu in številu.

Iz števila pojavnic in števila različnic istega kvantifikatorja smo izračunali podatek razmerja med pojavnicami in različnicami (RPR). To razmerje pokaže, kako raznolike so ustreznice enega kvantifikatorja v korpusu. Če je razmerje nizko, pomeni, da je rabljeno besedišče manj pestro in da je število ponovitev istih ustreznic $\mathrm{v}$ besedilu večje. Nasprotno, ko je to razmerje med pojavnicami in različnicami visoko, sklepamo, da je besedišče v prevodu bolj raznoliko in da ima posamezni kvantifikator večje število različnih prevodnih ustreznic.

8 Izpis besede ali besedne zveze iz korpusa z njenim besedilnim okoljem. 
Razmerje med pojavnicami in izpustom (RPI) smo izračunali iz števila vseh pojavnic kvantifikatorja in števila izpustov istega kvantifikatorja. Večji odstotek prikazuje višje število izpustov, nižji odstotek pa večjo ohranitev kvantifikatorjev v prevodu.

Obravnavali smo po dve najvišji in dve najnižji vrednosti, saj je včasih prišlo do velikih odstopanj med najvišjo in vsemi ostalimi vrednostmi, ali pa so bile razlike tako majhne, da se nam je zdelo prav, da omenimo prvi oz. zadnji dve mesti. Vse podatke smo zaokrožili na cela števila, decimalke pa pustili le tam, kjer je bilo to potrebno za razlikovanje.

PRIMERJAVA SPOOKA IN EVROKORPUSA

\begin{tabular}{|c|c|c|c|c|c|c|c|c|c|c|}
\hline $\begin{array}{c}\text { Nedoločni } \\
\text { kvantifikator }\end{array}$ & $\begin{array}{c}\text { število } \\
\text { FR } \\
\text { pojavnic }\end{array}$ & & $\begin{array}{l}\text { Število } \\
\text { SLO } \\
\text { različnic }\end{array}$ & & $\begin{array}{c}\mathrm{RPR}^{17} \\
(\%)\end{array}$ & (\%) & $\begin{array}{l}\text { število } \\
\text { izpustov } \\
\text { prevoda }\end{array}$ & (\%) & $\begin{array}{l}\mathrm{RPI}^{18} \\
(\%)\end{array}$ & (\%) \\
\hline & Spook & EvK & Spook & EvK & Spook & EvK & Spook & EvK & Spook & EvK \\
\hline $\begin{array}{l}\text { QUELQUES- } \\
\text { UN(E)S }\end{array}$ & 18 & 12 & 4 & 2 & $22 \%$ & $\begin{array}{l}17 \\
\%\end{array}$ & 0 & 1 & $0 \%$ & $8 \%$ \\
\hline CHACUN(E) & 178 & 240 & 10 & 5 & $6 \%$ & $2 \%$ & 23 & 45 & $13 \%$ & $19 \%$ \\
\hline PLUSIEURS & 193 & 129 & 19 & 9 & $10 \%$ & $7 \%$ & 9 & 2 & $5 \%$ & $2 \%$ \\
\hline CERTAIN(E)S & 201 & 265 & 11 & 9 & $5 \%$ & $3 \%$ & 17 & 26 & $9 \%$ & $10 \%$ \\
\hline CHAQUE & 434 & 131 & 18 & 5 & $4 \%$ & $4 \%$ & 18 & 9 & $4 \%$ & $7 \%$ \\
\hline QUELQUES & 750 & 123 & 22 & 8 & $3 \%$ & $7 \%$ & 45 & 14 & $6 \%$ & $11 \%$ \\
\hline TOUT(E) & 1.348 & 204 & 46 & 12 & $3 \%$ & $6 \%$ & 315 & 38 & $23 \%$ & $19 \%$ \\
\hline $\begin{array}{l}\text { TOUS/ } \\
\text { TOUTES }\end{array}$ & 1.242 & 262 & 25 & 7 & $2 \%$ & $3 \%$ & 224 & 25 & $18 \%$ & $10 \%$ \\
\hline skupaj $^{19}$ & 4.364 & 1.366 & 155 & 57 & $4 \%$ & $4 \%$ & 651 & 160 & $15 \%$ & $12 \%$ \\
\hline
\end{tabular}

Tabela 1: Primerjava rezultatov Spooka in Evrokorpusa

V tabeli št. 1 smo združili vse dobljene podatke iz obeh korpusov:

- najmanj pojavnic v Spooku in v Evrokorpusu ima quelques-un(e)s;

- $\quad$ največ pojavnic v Spooku ima tout(e), v Evrokorpusu certain(e)s;

- najnižje razmerje med pojavnicami in različnicami (RPR) v Spooku ima tous/ toutes v Evrokorpusu pa chacun(e);

- najvišje razmerje med pojavnicami in različnicami (RPR) v Spooku ima quelques-un(e)s, takoj za njim je plusieurs; enako je v Evrokorpusu, kjer ima quelques enako razmerje kot plusieurs;

\footnotetext{
$9 \mathrm{RPR}=$ razmerje med pojavnicami in različnicami

$10 \mathrm{RPI}=$ razmerje med pojavnicami in izpustom

11 »Skupnega« rezultata ne bomo analizirali, saj nas zanima obnašanje vsakega kvantifikatorja posebej.
} 
- najnižje razmerje med pojavnicami in izpustom (RPI) v Spooku ima quelques-un(e)s in v Evrokorpusu plusieurs;

- najvišje razmerje med pojavnicami in izpustom (RPI) v Spooku ima tout(e), v Evrokorpusu pa tout(e) in $\operatorname{chacun}(e)$.

$\mathrm{Na}$ začetku raziskave smo pričakovali, da bodo imeli nedoločni določevalniki, ki imajo v korpusu večje število pojavnic tudi večje število različnih prevodnih ustreznic. Predpostavka, da število pojavnic kvantifikatorja vpliva na njegovo pestrost pri prevajanju, se je izkazala za napačno. V Spooku je skoraj obratno: večja kot je pojavnost kvantifikatorja, manjša je njegova raznolikost pri prevajanju (nižje je njegovo RPR). Izjema je le plusieurs, ki ima malo ponovitev in visok RPR. Tudi pri Evrokorpusu se kaže enaka tendenca, le da razmerja med pojavnostjo in raznolikostjo prevodov niso razporejena tako enakomerno naraščajoče kot pri Spooku.

\subsection{Razmerje med pojavnicami in različnicami (RPR) v Spooku in Evrokorpusu:}

- je v Spooku višje od RPR v Evrokorpusu pri: quelques-un(e)s, chacun(e), plusieurs, certain(e)s;

- $\quad$ je v Evrokorpusu višje od RPR v Spooku pri: quelques, tout(e) in tous/toutes;

- je v Spooku enako kot v Evrokorpusu pri: chaque.

Pestrost prevodnih ustreznic v Spooku pripisujemo izvirnim literarnim besedilom in tudi ročnemu prevajanju. Obratno pripisujemo vzroke nizkega RPR v Evrokorpusu tipskim besedilom enega področja, strojnemu prevajanju in natančnemu (včasih togemu) pravniškemu jeziku, ki ne dopušča prevajalčeve izvirnosti. Če bi se lotili prevajanja vsakega stavka na novo, bi morda tudi v tem primeru dobili več različnih prevodnih ustreznic izbranih kvantifikatorjev.

Najnižja razlika med pojavnicami in različnicami v Spooku in Evrokorpusu se pojavi pri kvantifikatorju tous/toutes. Gre za $1 \%$ razlike v prid Evrokorpusa. Največji odstotek prevodnih ustreznic $\mathrm{v}$ obeh korpusih predstavljata kolektivni vsi. Na drugem mestu je distributivni vsak. V Evrokorpusu sta ti dve ustreznici rabljeni pri isti različnici kar v $86 \%$, v Spooku pa v 74 \%. Večina ostalih ustreznic je rabljena le enkrat ali dvakrat.

Presenetljivo je, da ostali zaimki v EvK ne izražajo celote, ki jo ponavadi pripisujemo temu celostnemu zaimku. Ostale prevodne ustreznice so večinoma rabljene le enkrat (poleg določen - dvakrat in kakršen - osemkrat). Več celostnih rešitev najdemo v Spooku. Edino v Spooku najdemo tudi dvojinski zaimek oba. S 4,9-\% pojavnostjo zaseda tretje mesto med prevodnimi rešitvami. Iz francoščine se ga da prevesti le na podlagi konteksta. Vse ostale rešitve v Spooku ne presegajo 0,3-\% pojavnosti. 
Najnižje razmerje RPR celostnega kvantifikatorja tous/toutes potrjuje našo predpostavko, da za izražanje celote ne potrebujemo ali nimamo številnih jezikovnih rešitev. Ustreznice, ki nam jih ponuja Spook, pojem celote dostikrat izpuščajo (najrazličnejši, noben, samo ...).

Druga najnižja razlika RPR je pri certain(e)s. Različnice v Spooku (RPR: 5 \%) so za $2 \%$ številčnejše od različnic v Evrokorpusu (RPR: 3 \%). Največji delež vseh prevodnih ustreznic prevzame ustreznica nekateri: $70 \% \mathrm{v}$ Spooku in 55 \% v Evrokorpusu. V Evrokorpusu ima velik odstotek tudi ustreznica določen (25\% pojavnic).

Najvišjo raznolikost med pojavnicami in različnicami v Spooku in Evrokorpusu ima quelques-un(e)s (5\% razlike). Na to vpliva tudi njegova maloštevilna pojavnost. Kljub visokemu RPR prevodne rešitve ne predstavljajo izrazito pomensko drugačnih prevodnih ustreznic (nekateri, nekaj, kakšen, drugi). Gre za sinonime, ki ostajajo na področju nedoločnega, a posegajo tudi v karakteristično identifikacijo referentov (nekateri, drugi).

Druga najvišja razlika RPR se pojavi pri chacun(e) in pri quelques, kjer gre za razliko 4 \%. Chacun(e) ima več različnic v Spooku, quelques pa več različnic v Evrokorpusu.

Nesporna prevodna ustreznica za chacun je v obeh korpusih vsak. V Spooku je rabljen v 77 \%, v Evrokorpusu pa v $71 \%$. Vse ostale ustreznice so rabljene izjemoma. V Spooku najdemo za chacun dosti več ustreznic (sleherni, noč za nočjo, lasten ...), za katere predvidevamo, da so lahko rabljene le v določenem kontekstu. Gre za besede, ki bi jih v strokovnem pravnem jeziku težko našli. Ustreznice, ki zvišujejo stopnjo raznolikosti, so večinoma rabljene izjemoma, le enkrat do štirikrat v celotnem korpusu.

Tudi za quelques v obeh korpusih močno prevladuje prevodna ustreznica nekaj. V Spooku se pojavi v 85 \%, v Evrokorpusu pa v $61 \%$. Zelo visoko stopnjo pojavnosti ima v Evrokorpusu še ustreznica nekateri. Pojavlja se kar v 20 \% (v Spooku se pojavi le v $2 \%$ ). Vse ostale prevodne rešitve so rabljene izjemoma. Tako se v EvK tri prevodne ustreznice pojavijo le enkrat, dve ustreznici se pojavita dvakrat in ena trikrat. Vse te prevodne ustreznice ostajajo na semantičnem polju nedoločne količine (malo, manjši, številen, nekoliko ...).

Čeprav je RPR za quelques višji v Evrokorpusu, je nabor njegovih ustreznic v Spooku po številu večji. Toda med široko paleto slovenskih ustreznic za quelques je pojavnost 19-ih ustreznic v Spooku, ki predstavljajo semantično bolj polnopomenske besede (hip, prgišče, čez leta, tu pa tam ...), manjša od $1 \%$.

Enako razmerje med pojavnicami in različnicami v Spooku in Evrokorpusu najdemo pri kvantifikatorju chaque. Njegov RPR v obeh korpusih je 4 \%. V obeh korpusih močno prevladuje ustreznica vsak. V Spooku se pojavlja v $70 \%$, poleg tega pa ima visoko pojavnost (14\%) še ustreznica vsakič/vsakokrat. V Evrokorpusu prevladuje le ustreznica vsak z 89-\% pojavnostjo.

Ostale prevodne rešitve v Spooku ne presegajo 1,6-\% pojavnosti (izjema je sleherni z 2,3-\% pojavnostjo). Gre večinoma za polnopomenske besede, ki zopet kažejo na literarna besedila in prosta prevajanja (kar naprej, slednji, nenehno ...). 
V EvK se poleg glavne prevodne ustreznice vsak pojavijo le še štiri ustreznice z izredno nizko pojavnostjo (od $0,8 \%$ do $1,5 \%$ ) in se ne oddaljujejo od primarnega pomena (npr. posamezen, vsakokrat ...).

\subsection{Razmerje med pojavnicami in izpustom prevoda (RPI) v Spooku in Evrokorpusu:}

- $\quad$ je v Evrokorpusu višje od RPI v Spooku pri quelques-un(e)s, chacun(e), certain(e) $s$, chaque in quelques;

- $\quad$ je v Spooku višje od RPI v Evrokorpusu pri plusieurs, tout(e) in tous/toutes.

Pri vseh izbranih nedoločnih določevalnikih se v obeh korpusih zelo visoko pojavlja kategorija »izpust prevoda«, kjer posamezni nedoločni določevalnik ni preveden. Tako visoke pojavnosti izpusta nismo pričakovali. Po odstotkih sicer ne zavzema večinskega deleža, a se pogosto pojavlja že na drugem mestu za prvo najpogostejšo prevodno ustreznico.

Predvidevali smo, da bo Evrokorpus ohranjal natančno strukturo izvornega jezika. V Evrokorpusu lahko pri podrobni analizi prevodnih ustreznic ugotovimo, da izvorni jezik prevoda ni francoščina, zaradi česar prihaja tudi do različnih prevodov istega stavka. Opazili smo tudi obratne primere, kjer se kvantifikatorji v drugih jezikih (npr. angleščina) ne pojavljajo in so dodani v prevodu.

V Spooku smo pri večini posameznih kvantifikatorjev opazili dosti manj izpustov. Zdi se, da kvantifikatorji nosijo pomemben del informacij v stavku. Zato jih literarna besedila in prosti prevodi ohranjajo bolj pogosto (izjema sta tous/toutes in plusieurs).

Vzroki izpusta kvantifikatorja pri prevajanju so različni: prevajalcem se lahko ne zdi potreben za doseganje pomena, lahko ga nadomestijo z drugimi besednimi strukturami, lahko je v stavku ciljnega jezika nesprejemljiv, lahko je odsoten v izvornem jeziku itn. Med vzroke prištevamo tudi tipska besedila, strojno prevajanje, natančen pravniški jezik, ki ne dopušča prevajalčeve izvirnosti... Ker ne poznamo jezikovne prevajalske verige, o izpustu pri prevajanju ne moremo natančno soditi. Včasih z izpustom res ne izgubimo ničesar, včasih pa gre za prevajalčevo odločitev ali morda celo nezbranost in se v prevodu izgubi tudi del pomena. Različne rešitve lahko le ugotavljamo, ne moremo pa soditi o njih. Morda bi bilo odstopanj v prevodih kvantifikatorjev manj, če bi bili vsi prevodi narejeni neposredno iz francoščine.

Najnižja razlika med pojavnicami in izpustom $\mathbf{v}$ obeh korpusih se pojavi pri certain(e)s (razlika je $1 \% \mathrm{v}$ prid EvK). Po stopnji izpusta se certain(e)s v obeh korpusih približuje povprečni vrednosti izpusta v posameznem korpusu. Temu kvantifikatorju smo pripisovali poleg kvantifikacijskih tudi velike karakteristične lastnosti. Ravno zaradi izražanja teh lastnosti bi pričakovali še manjši izpust pri prevajanju. Pogostost izpusta prevodov v obeh korpusih dokazuje, da se ga da nadomestiti tudi z drugimi prevodnimi rešitvami. 
Druga najnižja razlika (RPI) je pri chaque (razlika je 2,8 \% v prid EvK). Zopet se ponovi izpust celostnega kvantifikatorja, tokrat distributivnega (cf. supra: izpust chacun(e) in tous/toutes). Očitno tudi poudarjanje posameznega elementa iz množice ni potrebno za doseganje želenega pomena v prevodu. To lahko posplošimo tako za Spook kot EvK.

Najvišja razlika med pojavnicami in izpustom v Spooku in Evrokorpusu se pojavi pri tous/toutes (razlika je $8 \% \mathrm{v}$ prid Spooka) in pri quelques-un(e)s (razlika je $8 \%$ $\mathrm{v}$ prid Evrokorpusa).

Z ničtim izpustom v Spooku zopet izstopa kvantifikator quelques-un(e)s. Po semantični interpretaciji predvidevamo, da je v prostih oz. literarnih besedilih dosti težje izpustiti kvantifikator z zaimkovno vlogo. Pravni jezik ga očitno nadomesti z drugimi jezikovnimi elementi.

Kolektivni tous/toutes ima v Spooku najvišje RPI 18 \%, v Evrokorpusu pa le 10 \%.

Večkrat smo že omenili in lahko potrdimo, da je izpust tega kvantifikatorja lažji, ker v stavkih ni potrebno poudarjati celote. Kadar v stavku niso poudarjeni vsi elementi in tudi ni rabljen noben delni kvantifikator, takrat predpostavljamo, da se predikat nanaša na celotno množico izbranih elementov. Iz zadetkov v Spooku zaključujemo, da besedila iz Spooka manj poudarjajo vse elemente izbrane množice.

Po tej trditvi se upravičeno postavlja vprašanje, zakaj ima tudi quelques v EvK tako visoko stopnjo izpusta pri prevajanju. Razlika RPI za quelques med Spookom (RPI: 6 \%) in EvK (RPI: $11 \%$ ) je 5 \%. Njegova količinska semantična vrednost je manj natančna, zato bi vseeno pričakovali, da se bo ohranil tudi v prevedenih stavkih.

Naslednji primer (1) prikazuje veliko stopnjo odstopanja med slovenskim in francoskim stavkom v Evrokorpusu. V slovenskem stavku opazimo izpust nedoločnega določevalnika quelques in tudi izpust posameznih besed (supplémentaires). Vzrok smo iskali v prevajanju prek drugih jezikov. V EUR-lexu smo poiskali angleški stavek in vidimo lahko, da je bil slovenski prevod verjetno narejen iz angleškega, saj sta stavka bolj primerljiva.

1) a) FR: Quelques lignes directrices apportent des précisions supplémentaires: ... (EvK)

b) SL: Podrobnejšse smernice so naslednje: ... (EvK)

c) ANG: Following are more detailed guidelines: ... (EvK)

Odsotnost prevoda francoskega nedoločnega določevalnika, kjer bi se le-ta povsem upravičeno lahko pojavil v slovenskem prevodu, je opaziti predvsem v Evrokorpusu. Razlog je lahko tudi v izvirnem jeziku prevoda.

\subsection{Raznolikost slovenskih prevodnih ustreznic v Spooku in Evrokorpusu}

V tem poglavju želimo predstaviti raznolikost nabora ustreznic, ki smo jih našli v obeh korpusih. Včasih je bilo težko vse ustreznice razporediti v posamezne kategorije ali jih celo šteti kot prevod izbranega kvantifikatorja. To smo skušali narediti karseda pregledno, tako da smo kot prevodno ustreznico kvantifikatorja razumeli tudi besedne zveze v stavku, ki so na kakršenkoli način izražale nedoločno kvantifikacijo. 
Kljub zelo tesni razliki v odstotkih je zanimiv semantični pregled slovenskih ustreznic. V Spooku nastopa veliko besed, ki količino izražajo posredno ali pa so na prvi pogled celo nenavadne za izražanje količine (npr. tu pa tam). Večina prevodnih rešitev v Spooku opredeljuje količino s semantično bolj konkretnimi besedami (prgišče). Njihovo rabo lahko pripišemo literarnemu prevajanju, ki ni vpeto v kalupe pravnih besednih zvez.

Prevodne ustreznice v Evrokorpusu izražajo količino bolj striktno in se ne oddaljujejo od primarnega pomena nedoločnih kvantifikatorjev. Takšne rešitve pripisujemo natančnim besedilom in natančnemu prevajanju, kjer ni prostora za iskanje pestrih prevajalskih rešitev.

$\mathrm{V}$ primerjavi razmerij med prevodnimi različnicami in izpustom nas presenečajo visoki odstotki RPI v primerjavi s posameznimi RPR. Brez analize bi predpostavljali, da število prevodnih rešitev presega pojavnost izpustov. Toda po odstotkih pojavnosti $\mathrm{V}$ primerjavi z različnicami, se izpust kvantifikatorja uvršča:

- 10-krat na 2. mesto (chacun(e), chaque, tout(e), tous/toutes, quelques-un(e)s v EvK in chacun(e), certain(e)s, quelques, tout(e), tous/toutes v Spooku),

- $\quad$ 4-krat na 3. mesto (plusieurs, certain(e)s, quelques v EvK in chaque v Spooku),

- 1-krat na 4. mesto (plusieurs v Spooku) in

- 1-krat na 5. mesto (quelques-un(e)s v Spooku).

V primerjavi z izhodiščnimi prevodi, ki smo jih našli v slovarjih in jih predstavili v teoretičnem delu, so rezultati podobni. Pri številnih kvantifikatorjih obstaja ena sama prevodna ustreznica, katere pojavnost v enem ali obeh korpusih (večinoma močno) presega $50 \%$. Le pri kvantifikatorju tout (e) v nobenem od obeh korpusov nobena prevodna ustreznica ne presega $50 \%$. S $47 \%$ se najbolj približajo ustreznice (vsi/vse/ves) iz Spooka. Vse najpogostejše slovenske ustreznice smo zbrali v spodnji tabeli:

\begin{tabular}{|l|l|l|l|}
\hline $\begin{array}{l}\text { Nedoločni } \\
\text { kvantifikator }\end{array}$ & $\begin{array}{l}\text { Prevladujoče } \\
\text { ustreznice iz korpusov }\end{array}$ & $\begin{array}{l}\text { 2. oz. 3. najpogostejša } \\
\text { ustreznica iz korpusov }\end{array}$ & Slovarske ustreznice ${ }^{20}$ \\
\hline certain(e)s & nekateri & določen & nekateri \\
\hline chacun(e) & vsak & vsi/vse & vsak \\
\hline chaque & vsak & vsakič/vsakokrat & vsak \\
\hline plusieurs & več, večkrat & večkrat, nekaj & več \\
\hline quelques-un(e)s & nekateri, nekaj & kakšen & nekateri \\
\hline tout(e) & vsi/vse/ves, vsak & vsakič, karkoli & vsi, ves \\
\hline tous/toutes & vsi, ves & vsak, oba & ves, cel \\
\hline quelques & nekaj & nekateri, kakšen & kakšen, nekaj \\
\hline
\end{tabular}

Tabela 2: Najpogostejše slovenske ustreznice

12 Grad, elektronski slovar 
V tabeli št. 2 so prikazane prevodne ustreznice, ki smo jih prepisali iz francosko-slovenskega slovarja (Grad, elektronski slovar) in ustreznice, ki smo jih dobili na podlagi analize obeh korpusov. Vidimo, da se ene in druge ustreznice ujemajo. Zaključujemo, da so v slovarjih ponujene besede, ki nedvoumno izražajo nedoločno količino, vse ostale rešitve, ki jih najdemo v Spooku, pa so prepuščene prevajalčevi jezikovni spretnosti. Čeprav teh ustreznic v slovarjih ne najdemo, zanje ne moremo trditi, da so napačne. Morda bi se jih dalo vključiti v kakšen razširjen literarni francosko-slovenski slovar. Veliko število raznolikih prevodnih ustreznic potrjuje širok pomenski doseg obravnavanih kvantifikatorjev.

\section{3}

\section{IZSLEDKI KORPUSNE ANALIZE}

Pred začetkom primerjalne analize Spooka in Evrokorpusa smo pričakovali številne možne rešitve in razlike v samih prevodih francoskih kvantifikatorjev v slovenščino. To nas je vodilo do hipoteze, da bo verjetno težko najti le eno sprejemljivo prevodno ustreznico za določen kvantifikator. Izsledki kvalitativne in kvantitativne raziskave prevodnih rešitev v korpusih so nas pripeljali do tega, da moramo hipotezo o številnih možnih rešitvah delno ovreči. Prišli smo namreč do rezultatov, da ima vsak nedoločni kvantifikator (v obeh korpusih) vedno le eno močno prevladujočo slovensko ustreznico. Vseeno se v korpusih (predvsem v Spooku) pojavlja več različnih ustreznic, s katerimi so prevajalci prenesli pomen izvornega stavka.

Toda podroben pregled podatkov o posameznih kvantifikatorjih daje različne odgovore na omenjeno hipotezo. Ločena obravnava kvantifikatorjev nam nudi več informacij, saj vidimo njihovo obnašanje na različnih ravneh. Različne vrednosti kažejo specifično obnašanje vsakega kvantifikatorja posebej in njegovo specifično vlogo v kontekstu. Res smo v Spooku po številu našli dosti več prevodnih različnic za en kvantifikator, a odstotne vrednosti so pri nekaterih nedoločnih kvantifikatorjih pokazale nasproten rezultat. Vzrok visoke pestrosti prevodnih ustreznic v Evrokorpusu je verjetno pogojen tudi z izredno pestrimi tematikami in obsežnostjo baze podatkov. Kljub omejitvi izpisa zadetkov smo dobili veliko število različnih prevodnih ustreznic za posamezne nedoločne kvantifikatorje.

Prišli smo do sledečih rezultatov:

- $\quad$ večjo pestrost prevodnih ustreznic v Spooku izkazujejo: quelques-un(e)s, chacun(e), plusieurs, certain(e)s,

- $\quad$ večjo pestrost prevodnih ustreznic v Evrokorpusu izkazujejo: quelques, tout(e), tous/ toutes,

- $\quad$ enako stopnjo pestrosti prevodnih ustreznic v Spooku in Evrokorpusu izkazuje: chaque.

Prevajalci iščejo različne rešitve, s katerimi se želijo po pomenu in intenci sporočila približati izvirniku. V Spooku se pojavlja veliko število prevodnih ustreznic, ki skušajo 
ustrezati slogu pisanja ali kontekstu. Te besede so v izvirniku vedno enake (omenjeni nedoločni kvantifikatorji), v slovenščini pa jih zamenjuje veliko število raznolikih besed. Analiza prevodnih rešitev obeh korpusov je pokazala izredno raznolikost slovenskih ustreznic vseh osmih »izbranih kvantifikatorjev«, pri čemer so številne ustreznice rabljene le enkrat.

Pestrost pa ni odvisna le od avtorja, temveč tudi od prevajalca, ki skuša s svojo izbiro ustreznega prevedka kar najbolj prenesti pomen. Pričakovali bi lahko, da bo prevajalec ohranjal osnovne prevode in ne bo iskal drugih možnosti. Toda izkazalo se je, da so predvsem prevajalci tisti, ki so odgovorni za rabo raznolikih besed slovenskega jezika. Raznolikost prevodnih ustreznic je pokazala, da ima tudi slovenščina zelo bogate možnosti izražanja nedoločne količine. Slednja je vedno vpeta med ekstenzijo (razsežnostjo vseh predmetov na svetu, na katere se nanaša samostalniška zveza), ekstenziteto (količino elementov v dani množici) in ekstenzivnostjo (primeri, kjer je stavek resničen). Vse to je določeno z ožjim in širšim kontekstom ter z zunajjezikovnimi dejavniki.

Različne prevodne ustreznice, ki smo jih našli za izbrane nedoločne kvantifikatorje, in njihovi izpusti v prevodu kažejo, da se enega jezika ne da preslikati v drugega. Upoštevati je potrebno načine izražanja, ustaljene besedne zveze, zakonitosti vsakega jezika in nenazadnje tudi sporočilno vrednost. Glede na številne raznolike rešitve težko govorimo o vplivu posameznega avtorja na dobljene rezultate. S tem potrjujemo hipotezo, da se zaradi velikega nabora besedil in tudi zaradi ročnega prevajanja porazgubi vpliv posameznega avtorja.

$\mathrm{Na}$ začetku analize obeh korpusov nismo posebej razmišljali o izpustu kvantifikatorjev v prevodih, saj ga nismo pričakovali. Na prve izpuste prevodov kvantifikatorjev v slovenščini smo naleteli zelo hitro in ugotovili, da lahko tudi stavki brez kvantifikatorjev izražajo kvantifikacijo. Ravno zaradi »odsotnosti« prevedka ostanejo nezabeleženi ali celo pozabljeni kot možnost pri prevajanju. Pogosto lahko izpuščanje besed pri prevajanju razumemo kot slab prevod. Toda na številnih primerih smo videli, da lahko stavek kljub izpustu prevoda kvantifikatorja ohrani svoj pomen. Dokazali smo, da so SZ brez kvantifikatorja pojmovane celostno, kar opravičuje pogost izpust celostnih kvantifikatorjev $^{13}$. Da je izpust pri celostnih (distributivnih in kolektivnih) kvantifikatorjih najpogostejši, je razumljivo, saj (francoska in slovenska) SZ brez kvantifikatorja predstavlja njeno totaliteto in zato ne potrebuje kvantifikatorja.

Torej izpusta slovenskega kvantifikatorja in nenatančnega prevoda ne moremo vedno povezovati. Včasih bi bil prevod kvantifikatorja v slovenščini celo posiljen. To se pogosto zgodi pri certains/nekateri, kadar ga prevajalci na vsak način želijo prevesti. V takih primerih pogosto rabijo ustreznico določen, ki običajno ni najprimernejša.

Zavedati se moramo, da je lahko tudi drugačna jezikovna struktura tista, ki dovoljuje ali daje prednost izpustu kvantifikatorja. Na primerih smo videli, da lahko izpust

$13 \mathrm{~V}$ anketi smo analizirali tudi stavke brez kvantifikatorjev in preverili njihovo razumevanje pri govorcih obeh jezikov. Izkazalo se je, da je večina stavkov brez kvantifikatorjev razumljena celostno. V manjšini so bili odgovori, ki so potrjevali delno interpretacijo. 
nedoločnega kvantifikatorja pred SZ spremeni pomen SZ in posredno tudi stavka. Kadar je kvantifikator odsoten, razumemo SZ v njeni celoti. Kadar pa želimo izraziti delnost, jo je potrebno natančno omeniti.

Če pogledamo povprečje vseh kvantifikatorjev, vidimo, da je razmerje med izpustom in pojavnicami (RPI) za $2 \%$ višje v Evrokorpusu. Na podlagi povprečja rezultatov moramo ovreči hipotezo, da je izpust prevoda kvantifikatorjev manj pogost v Evrokorpusu. To smo predvidevali zaradi natančnosti in togosti pravnega jezika.

Do raznolikih odgovorov na to hipotezo nas privede podrobna analiza kvantifikatorjev:

- Le trije kvantifikatorji potrjujejo hipotezo o številčnejšem izpustu prevodov v Spooku. V Spooku so v slovenščini pogosteje izpuščeni: plusieurs, tout(e) in tous/toutes. - Hipotezo, da je stopnja izpusta prevodov višja v Spooku, moramo zavrniti za: quelques-un(e)s, chacun(e), certain(e)s, chaque in quelques. Vsi našteti kvantifikatorji so pogosteje izpuščeni v slovenskih prevodih Evrokorpusa.

Razlika v stopnji izpusta med temi tremi kvantifikatorji je zelo visoka: pri obeh celostnih kvantifikatorjih gre za visoko stopnjo izpusta (RPI: $10 \%-23 \%$ ), pri delnem plusieurs/več pa za zelo nizko (RPI: $2 \%-5 \%$ ). Visoka stopnja izpusta v Spooku pri tout je pogosto vezana na različne vrste prevodnih ustreznic. V slovenščini najdemo prevod v obliki superlativa ali pa gre za ustaljene besedne zveze: de toute évidence (očitno), de toute façon (kakorkoli) ${ }^{14}$.

Naj gre za delne ali celostne kvantifikatorje, očitno je, da ima raba vsakega posameznega kvantifikatorja svoje značilnosti. Tako smo pokazali, da je očitno lažje izpuščati celostne kvantifikatorje, a moramo chaque/vsak izvzeti iz te trditve.

Vse dobljene odstotne vrednosti so si blizu. Pri nobenem kvantifikatorju nismo zaznali velikega odstopanja, ki bi nakazovalo povsem drugačno obnašanje v enem ali drugem korpusu. Največje razlike posameznega kvantifikatorja med enim in drugim korpusom ne presegajo $8 \%$. Razlike bi lahko dostikrat merili celo v decimalkah, saj so manjše od $1 \%$. Tudi te majhne odstotne razlike pri izračunanih razmerjih kažejo na podobnosti med korpusoma.

Vse različne interpretacije enega samega leksema lahko imenujemo »ohlapne rešitve«. Ohlapne jih imenujemo zato, ker nam nudijo številne različne pomene, a ni nujno, da nas pripeljejo do določenega pomena. Ta pomen se izoblikuje šele v odnosu do nanosnika, predikata in konteksta. Vseeno je slovarsko naštevanje osnovnih rešitev nujno potrebno. Da bi uporabniku slovarja z bogatim naborom prevodnih ustreznic omogočili tudi njihovo kvalitetno rabo, se kot nujnost kaže raba kvalifikatorjev, besednih zvez in primerov. Le na ta način lahko govorca pripeljemo do iskanega pomena.

Zaključujemo, da so prevodne rešitve obeh korpusov v pomoč pri prevajanju in proučevanju možnih načinov prevajanja nedoločnih izrazov iz francoščine v slovenščino in

14 Kar bi lahko prevedli tudi s kvantifikatorjem: na vsak način. 
obratno. Ugotovili smo, da se za nedoločne kvantifikatorje pojavljajo številne različne prevodne ustreznice, ki so odvisne od konteksta, in zato ni priporočljivo zatekanje zgolj k dvojezičnim slovarjem. Veliko število različnih in pestrih prevodov je pokazalo možnost bolj poljubnega prevajanja in hkrati pestrost sistema slovenskih kvantifikatorjev. Tudi izolirani prevodni primeri so vedno pomensko vpeti v sobesedilo. Enako velja za posamezne besede, ki se nam v »izoliranem« stavku zdijo nepovezane, v kontekstu pa dobijo vlogo, ki je pomensko povezljiva s sobesedilom.

Glede na ugotovitve, je potrebno med francosko-slovenske prevajalske rešitve vključiti možnost izpusta prevoda kvantifikatorja. Francoščina potrebuje določevalnike. Slovenščina ne. Tudi tu je razlog, da se pri prevajanju pogosto začuti vpliv francoskih določevalnikov v slovenskih stavkih. Slovenski stavek je brez teh določevalnikov lahko lepši in bolj jasen. Tudi v jeziku lahko uporabimo pravilo: manj je več.

Spodaj predstavljamo tabelo predlaganih prevodnih ustreznic:

\begin{tabular}{|l|l|l|}
\hline Količina & slovenski kvantifikator & francoski kvantifikator \\
\hline Najnižja delna količina & nekaj & quelques, quelques-un(e)s \\
\hline Večja delna količina & več, večkrat & plusieurs \\
\hline Karakteristična delna količina & nekateri & certains, quelques-un(e)s \\
\hline Celostna količina & vsak, vsi (ves) & $\begin{array}{l}\text { tout(e), tous/toutes, chaque, chacun(e), } \\
\text { možnost izpusta prevoda }\end{array}$ \\
\hline
\end{tabular}

Zaključujemo z mislijo, da jezik, naj bo umetniško-literarni ali pravni, vendarle ni tako različen. Vse kaže na to, da ga »proizvajamo« ljudje z lastnimi in včasih skupnimi miselnimi procesi, ki svojega načina mišljenja in izražanja ne spreminjamo glede na področje. Količino izražamo glede na notranje vzvode in percepcijo sveta. Čeprav smo sposobni svoj diskurz prilagoditi določenemu področju, pri tem ne prilagajamo semantičnih vrednosti besed. Besede ohranjajo svoj pomen, a ga vsakič prilagodijo svojemu pojavnemu okolju.

\section{4}

\section{ZAKLJUČEK}

Videli smo, da kvantifikatorji ne dajejo le podatka o količini, temveč nudijo mnoge druge informacije. Številne semantične ustreznice, ki smo jih razbrali iz korpusov, razkrivajo njihov širok in pomensko odprt doseg.

Kljub drugačnim začetnim pričakovanjem potrjujemo, da prav velikega odstopanja med francoskimi in slovenskimi nedoločnimi kvantifikatorji nismo zaznali. S številnimi primeri smo dokazali, da lahko v klasifikaciji med francoskim in slovenskim sistemom potegnemo številne vzporednice: francoski določevalniki pogosto ustrezajo slovenskim pridevniškim zaimkom in francoski zaimki pogosto ustrezajo slovenskim samostalniškim 
zaimkom. Tudi prevodi posameznih kvantifikatorjev so pokazali, da ima vsak francoski nedoločni kvantifikator močno prevladujočo slovensko ustreznico.

Vse to nas napeljuje k misli na univerzalno percepcijo nedoločne količine (nedoločnih) kvantifikatorjev pri vseh ljudeh, kjer vsak jezik s svojimi besedami še vedno izraža različne odtenke količine. Tudi odstopanj v razumevanju izražene količine ne moremo pripisovati posameznemu jeziku, temveč posamezniku.

Gola preslikava posameznih besed iz enega jezika v drugega je nemogoča. Potrebna je tudi preslikava pomena, ki ga dosežemo s strukturami in koriščenjem drugih značilnosti vsakega jezika. Z interpretacijami ohranjamo pomen stavka, ki ga želimo prenesti iz enega jezika v drugega. Da lahko to dosežemo, rabimo prevodne ustreznice, s katerimi najdemo pot do tega pomena. Kakor pove têrmin prevodne ustreznice, ne gre le za dobesedne prevedke, temveč moramo iskati besede, ki nam posredujejo želeni pomen. Včasih pa je celo treba kakšno besedo v prevodu tudi izpustiti.

\section{VIRI IN LITERATURA}

BARKER-PLUMMER, Dave/Jon BARWISE/John ETCHEMENDY (1999) Language, proof and logic. CSLI Publications.

BARWISE, John/Robin COOPER (1981) Generalized Quantifiers and Natural Language. Linguistics and Philosophy 4, no. 2, 159-219.

BOSVELD-DE SMET, Léonie (1994) Indéfinis, quantificateurs généralisés, lecture existentielle et lecture non-existentielle. Faits de langues n 4 , 129-137.

BOSVELD-DE SMET, Léonie/Marlene VAN PETEGHEM/Daniele VAN DE VELDE (2000), De l'indétermination à la qualification: les indéfinis. Arras: Artois presses Université.

CHARAUDEAU, Patrick (1992) Grammaire du sens et de l'expression. Paris: Hachette. CORBLIN, Francis (1996) Quantification et anaphore discursive : la référence aux complémentaires. Langages 123, 51-74.

CORBLIN, Francis (1997) Les indéfinis: variables et quantificateurs. Langue française $116,9-32$.

CORBLIN, Francis (2002) Représentation du discours et sémantique formelle: introduction et application au français. Paris: PUF

CORBLIN, Francis. (1987) Indéfini, défini et démonstratif. Constructions linguistique de la référence. Genève: Librairie Droz S.A.

CORBLIN, Francis/Henriette DE SWART (ur.) (2004) Handbook of French Semantics. Stanford (California): CSLI Publications.

DOBROVIE-SORIN, Carmen/Claire BEYSSADE (2004) Définir les indéfinis. Paris: CNRS Editions.

Dvojezični slovarji DZS: http://slovarji.dzs.si/ 
Evrokorpus. December 2017. http://evrokorpus.gov.si/

FLAUX, Nelly/Danièle VAN DE VELDE/ Walter DE MULDER (1997) Entre général et particulier: Les déterminants. Arras: Artois Presses Universite.

FLAUX, Nelly (2008) Les pronoms indéfinis en français: Une classe a (re)définir. In : Travaux de linguistique. 2008/1 ( ${ }^{\circ}$ 56). 7-46.

GALMICHE, Michel (ur.) (1977) Quantificateurs, référence et théorie transformationnelle. In: Langages, $11^{e}$ année, $n^{\circ} 48.3-49$.

GEERAERTS, Dirk/Claude VANDELOISE (ur.) (1991) Grammaire cognitive et sémantique lexicale. In: Communications, 53. 17-50.

GIANNAKIDOU, Anastasia (ur.) (2009) Quantification, definiteness, and nominalization. Oxford: Oxford University Press.

GigaFida. December 2017. http://www.gigafida.net/

GONDRET, Pierre (1976): Quelques, plusieurs, certains, divers: une étude sémantique, Français dans le monde XLIV, 1976. 143-152.

GREVISSE, Maurice (2004) Le bon usage. Bruxelles: Duculot.

KLEIBER, G. (1995) Sur les (in)définis en général et les SN (in)définis en particulier. Bulletin de la Société de Linguistique de Paris, xc, 1. 21-51.

KLEIBER, Georges (1994) Anaphores et pronoms. Louvain-la-neuve: Duculot.

KLEIBER, Georges (1994) Qu'est-ce qui est (in)défini ? In: Faits de langues $n^{\circ} 4$. 81-87.

KLEIBER, Georges (2001) Déterminants indéfinis ou quand les faibles jouent aux forts. Blanco, X. et al. (ur.) Détermination et formalisation. Lingvisticae investigationes, Supplementa, v.23. Amsterdam: Juhn Benjamins Publishing Co, 195-218.

KLEIBER, Georges (2002) Marqueurs référentiels et théorie du centrage, Linx, 47. 107-119.

KLEIBER, Georges (2011) La quantification universelle en trio : tous les, chaque et tout. Studii de lingvistică 1, $139-157$.

KLEIBER, Georges (ur.) (2001) Indéfinis: lecture existentielle et lecture partitive. In: Typologie des groupes nominaux. Rennes: PUR. 47-98.

Le Bon Usage. December 2017. http://www.lebonusage.com

LEEMAN, Danielle (2004) Les déterminants du nom en français: syntaxe et sémantique. Paris: PUF.

MARI, Alda (2006) Collectif vs distributif. In D. Godard, L. Roussarie et F. Corblin (éd.) Sémanticlopédie: dictionnaire de sémantique, GDR Sémantique \& Modélisation, CNRS MEZEG Adriana (2011) Korpusno podprta analiza francoskih polstavkov in njihovih prevedkov v slovenščini (doktorska disertacija), Ljubljana: FF.

MILNER Jean-Claude (1982) Ordres et raisons de langue. Paris: Seuil.

MULLER Claude (2001) Les déterminants indéfinis. Blanco, X. et al. (ur.) Détermination et formalisation. Lingvisticae investigationes, Supplementa, v.23. Amsterdam: Juhn Benjamins Publishing Co, 255-272.

MULLER, Claude (2006) Indéfinis vagues, cardinaux et distributivité. Corblin F., Ferrando S. \& Kupferman L. (ur.): Indéfini et prédication. Presses de 1'Université Paris Sorbonne, 461-476. 
PERKO, Gregor (2002) Kako obravnavati francoske pragmateme (teoretski in slovaropisni pristop). Vestnik, Letn. 36, št. 1/2, 295-307

PERKO, Gregor/Adriana MEZEG (2012) Uporaba francosko-slovenskega vzporednega korpusa pri slovarski analizi nekaterih mejnih področij idiomatike. Šorli, M. (ur.) Dvojezična korpusna leksikografija: slovenščina v kontrastu: novi izzivi, novi obeti. 12-34. RIEGEL, Martin/Jean-Christophe PELLAT/René RIOUL (1994) Grammaire méthodique du français. Paris: PUF.

SCHLAMBERGER BREZAR, Mojca (2005) Nekatere skladenjske značilnosti prevodov iz francoščine v slovenščino. Slovenščina in njeni uporabniki v luči evropske integracije. Koper : Univerza na Primorskem, Znanstveno-raziskovalno središče, Založba Annales: Zgodovinsko društvo za južno Primorsko. 261-268.

SCHLAMBERGER BREZAR, Mojca (2004) Diskurzivni pristop k problemu določnosti v slovenščini. Jezik in slovstvo št. 5, Ljubljana, 35-43.

SCHLAMBERGER BREZAR, Mojca (2009) Metodološki postopki v kontrastivnih raziskavah. V Sodobne metode v prevodoslovnem raziskovanju (ur. Nike K. Pokorn) Ljubljana: Znanstvena založba Filozofske fakultete, 132-145.

SCHLAMBERGER BREZAR, Mojca et al. (2005) Prevajanje in tolmačenje strokovnih besedil v Sloveniji in Evropski uniji. Slovenščina in njeni uporabniki v luči evropske integracije. Koper: Univerza na Primorskem, Znanstveno-raziskovalno središče, Založba Annales: Zgodovinsko društvo za južno Primorsko. 269-283.

Spook December 2017. http://nl.ijs.si/spook/konkor/

SSKJ December 2017. http://bos.zrc-sazu.si/sskj.html

TOPORIŠIČ, Jože (1982) Nova slovenska skladnja. Ljubljana: DZS.

TOPORIŠIČ, Jože (2004) Slovenska slovnica. 4., prenovljena in razširjena izd. Založba obzorja Maribor

Trésor de la langue française informatisé (TLFi) December 2017. http://atilf.atilf.fr/

VAN DE VELDE, Danièle (2005) Les interprétations partitive et existentielle des indéfinis dans les phrases existentielles locatives. Travaux de linguistique, no. 1, 37-52. VIDOVIČ MUHA, Ada (1979) Pridevniške zaimenske besede. XV. SSJLK. Ljubljana: Filozofska fakulteta, 65-97.

VIDOVIČ MUHA, Ada (1996) Določnost kot besedilna prvina v slovničnem opisu slovenskega jezika: (ob Kopitarjevi slovnici), Kopitarjev zbornik (Obdobja; 15), 115-130.

VINTAR, Špela (2001) Računalniška orodja za jezikoslovce in prevajalce. 37. seminar slovenskega jezika, literature in kulture. 319-332.

VINTAR, Špela/Darja FIŠER (2009) Gradnja in analiza korpusov za prevodoslovne raziskave. (ur. N.K. Pokorn) Sodobne metode v prevodoslovnem raziskovanju. Ljubljana: Znanstvena založba Filozofske fakultete, 80-109.

WAGNER, René-Luis/Jacqueline PINCHON (1969) Grammaire du français classique et moderne. Paris: Hachette

WEIGAND, Edda (ur.) (1988) Contrastive Lexical Semantics, Amsterdam; Philadelphia: J. Benjamins, 25-44. 
WILMET, Marc (1983) Les déterminants du nom en français : essai de synthèse. Langue française 57, 15-33.

WILMET, Marc (1986) La détermination nominale: quantification et caractérisation. Paris: PUF.

WILMET, Marc (1997) Grammaire critique du français. Paris: Hachette supérieur.

\section{POVZETEK}

Članek je namenjen analizi izražanja količine z nedoločnimi kvantifikatorji v francoščini in slovenščini. $\mathrm{V}$ francoščini smo proučevali nedoločne zaimke in nedoločne določevalnike, v slovenščini pa njihove ustreznice: nedoločne pridevniške in samostalniške zaimke ter števnike. Izhajali smo iz francoščine.

V članku smo na podlagi primerjav dveh francosko-slovenskih korpusov iskali pomenske ustreznice nedoločnim kvantifikatorjem. Dobili smo presenetljivo veliko število različnih prevodnih rešitev, a še vedno so največji delež med prevodnimi rešitvami zavzeli izbrani kvantifikatorji. Dokazali smo, da jih je kljub slovarskim prevodnim ustreznicam mogoče prevesti s številnimi drugimi ustreznicami. Dokazali pa smo tudi, da je lahko prevod francoskega kvantifikatorja (predvsem celostnega) v slovenskem stavku izpuščen, ne da bi se pri tem izgubil pomen izvornega stavka.

Ključne besede: nedoločni kvantifikatorji, korpusna analiza, prevodne ustreznice, Evrokorpus, Spook

\section{ABSTRACT}

\section{Use of Indefinite Quantifying Pronouns in Two French-Slovene Corpuses: Spook and Evro- korpus}

The article gives a comprehensive analysis of the quantity of indefinite quantifiers in French and Slovene, in which French provided the basis for finding Slovene equivalents. In the corpus based approach the semantic equivalents of indefinite quantifiers are put forward on the basis of a detailed comparison of two French-Slovene corpuses, which yielded a surprisingly large amount of different translation equivalents, the largest quantity of which are represented by the chosen quantifiers. It has been proven that despite the lexical translation equivalents, they can be translated with numerous other equivalents. However, sometimes there is also the possibility to omit the translation of quantifiers in Slovene without losing the meaning of the original French sentence.

Key words: indefinite quantifiers, corpus analysis, translation equivalents, Evrokorpus, Spook 